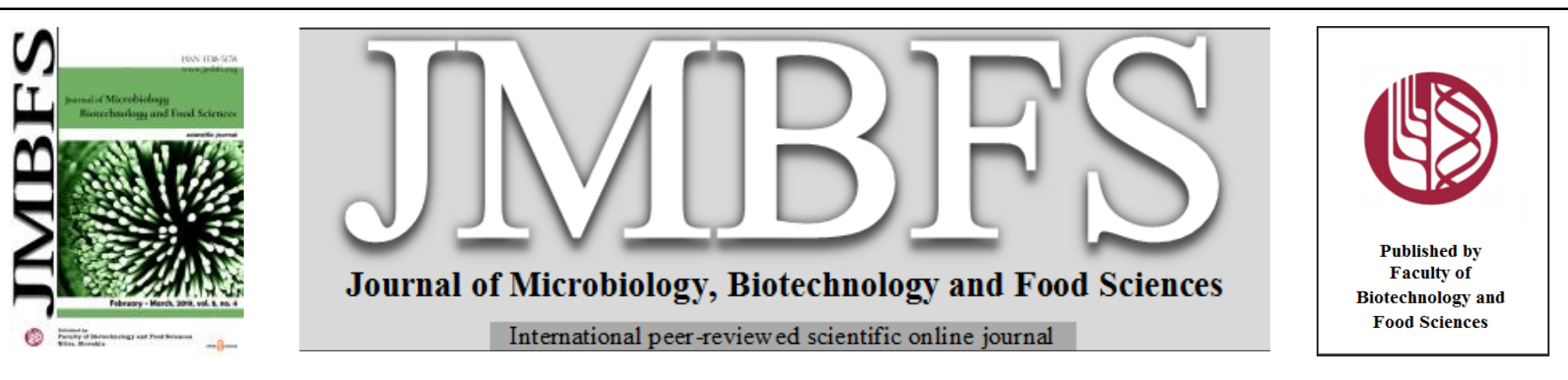

\title{
RESTRICTION POLYMORPHISM OF Mal d 1 ALLERGEN PROMOTOR IN APPLE VARIETIES
}

\author{
Jana Žiarovská*l, Jana Bilčiková ${ }^{2}$ Veronika Fialková , Lucia Zeleñáková3, Lucia Zamieškovál
}

Address(es): doc. Ing. PaedDr. Jana Žiarovská, PhD.,

${ }^{1}$ Slovak University of Agriculture in Nitra, Faculty of Agrobiology and Food Resources, Department of Genetics and Plant Breeding, Tr. A. Hlinku 2, 94976 Nitra, Slovakia.

${ }^{2}$ Slovak University of Agriculture in Nitra, Research centre Agrobiotech, Tr. A. Hlinku 2, 94976 Nitra, Slovakia.

${ }^{3}$ Slovak University of Agriculture in Nitra, Faculty of Biotechnology and Food Resources, Department of Food Hygiene and Safety, Tr. A. Hlinku 2, 94976 Nitra, Slovakia.

*Corresponding author: jana.ziarovska@uniag.sk

doi: $10.15414 / j m b f s .2019 .8 .5 .1217-1219$

ARTICLE INFO

Received 31. 5. 2018

Revised 15. 11. 2018

Accepted 15. 1. 2019

Published 1. 4. 2019

Regular article

OPEN OACCESS

\section{ABSTRACT}

Apples are the most consumed fruit in the European Union with the exception of citrus fruits and apple consumption is part of a healthy and balanced diet. Although apples are recommended to consume each day, they are one of the fruits that can trigger an allergic reaction. The most important apple allergen in Central and Northern Europe is Mald 1. The aim of the study was to analyse natural restriction pattern variability of the part of $\mathrm{Ypr} 10$ gene promotor in four apple varieties. All the analysed varieties resulted in different cleavage profiles for Ase I and Spe I when compared to the virtual cleavage profile of the genomic sequence stored in the public nucleotide database.

Keywords: restriction variability; Mal d 1; promotor; apple varieties

\section{INTRODUCTION}

Food provides to humans basically nutrients and energy for the activity. When properly formulated, it provides enough of the necessary substances, vitamins and microelements for the life. Food should only benefit by keeping the proper and healthy nutrition. Nevertheless, an unpleasant and damaging response to food exist in human organism. These are undesirable food reactions or their clinically more serious part - food allergies (Keresteš et al., 2011). Food allergy has an immunological background, particularly in the loss of immunological tolerance to dietary ingredients, which also manifests itself in an inadequate immune response to food antigens - especially proteins (Fuchs, 2013). Allergic diseases arise from many causes that complement together and overlap in their action. The condition is the repeated interaction of the organism with the externally occurring allergen. An important role in allergy is played by the inheritance, the ability of the organism to prevent the influence of various infectious and non-infectious pollutants, the quality of the function of the nervous and endocrine system, the influence of the environment and some other influences (Petru, 1994).

Apples are one of the oldest, most desirable and most used fruits in the world and among fruit, they possess the greatest measure in harmonious nutrition of the population. They are versatile in the useand are grown not only for direct consumption but also for drying, preserving or for further processing (Luby, 2003). For millennia, apples are breeded and cultivated to meet the demands of not only the consumers. There are over 7000 varieties, but only a few dozen are usedcommercially, such as Golden Delicious, Gala, Jonagold and Red Delicious. Apple consumption is part of a healthy and balanced diet (Szamos, 2011). They are the most consumed fruit in the EU with the exception of citrus fruits. Due to the availability of fruit throughout the year, apples are a very important source of secondary plant metabolites (Kiewning, 2013).

Although apples are recommended to consume each day, they are one of the fruits that can trigger an allergic reaction (Pagliarany et al., 2013). Apple can cause oral allergy syndrome (Kollmann et al., 2013) Actually, about $11.5 \%$ of children aged 0-6 years are allergic to apples and 6.6\% of adults (Kiewning $\boldsymbol{e t}$ al., 2013). Apple allergy is a common phenomenon in patients who have birch pollen allergy. Allergists have reported, that patients tolerate one apple (Gilissen et al., 2005). Apple varieties are divided into high, medium and low allergenic potential groups (Kiewning, 2014). The literature reports that Golden Delicious is a highly allergenic variety, while Santana is identified as a low allergenic variety (Gilissen, 2005).
Four major allergens are described in apples - Mal d 1, Mal d 2, Mal d 3 and Mal d 4. Mal d 1 and Mal d 4 allergens are thermolabile and sensitive to proteolytic degradation, while Mal d 2 and Mal d 3 allergens are resistant to heat and stable to proteolytic degradation. Mal d 1 and Mal d 2 are the most important apple allergen inducing an IgE response (Szamos et al., 2011). The most important apple allergen in Central and Northern Europe is Mal d 1. Mal d 1 is the homolog of the Bet $\mathrm{v} 1$ family, especially due to the high sequence identity and structural similarity between Mal d 1 and Bet v 1 (Somkuti et al., 2013). Both allergens Bet $\mathrm{v} 1$ and Mal d 1 belong to the pathogenesis-related proteins (PR-10 proteins) (Breiteneder and Ebner, 2000). The PR-10 genes appear in a large number of vascular plants (Somkuti, 2013). PR-10 proteins associated with pathogenesis have been described as proteins with ribonuclease activity and ability to bind cytokinins, steroids or DNA. Interestingly, no specific feature for PR-10 proteins has been found so widely in many plants (Beuning, 2004). Mal d 1 ( $Y p r 10$ gene) was firstly characterized, isolated and cloned in 1995. Several isoforms and variants were identified. Mal d 1 is considered to be the major allergen of an apple that causes allergy (Pühringer et al., 2000). The Mal d 1 allergen is a 17 18-kDa protein, 159 amino acids encoded by nucleotides 480-483 (Gao et al., 2005). Variant Mal d $1 \mathrm{~b}$ has 158 amino acids. The beta structure consisted of 33 (21\%). $62(39 \%)$ and 159 subunits that are included in spiral and beta-leaf components. The Mal d 1 allergen structure consists of seven strings and one long and short spiral (Somkuti et al., 2013). Mal d1 allergen comprise from set of genes structured from 31 different loci where each encoding another isoform. In addition, for each isoform, there are a number of slightly different alleles that can code for iso-allergen variants, which increases the Mal d 1 protein variability. Isoallergens may vary widely in their allergenic properties, but it is not clear which of these proteins are more involved in the allergic reaction (Pagliarany $\boldsymbol{e t}$ al., 2013).

The aim of the study was to analyse natural restriction pattern variability of the part of $\mathrm{Ypr} 10$ gene promotor in three cabinet varieties of apples compared to Santana variety and virtual cleavage pattern based on the Mal d 1 genomic sequence stored in the public nucleotide database.

\section{MATERIAL AND METHODS}

\section{Biological material and DNA extraction}

Apple varietes used in the study (Santana, Cripps Pink, Jonagold and Gala) were bought in local stores. Total genomic DNA was extracted by Gene JET Plant 
Genomic DNA mini Kit (Thermo Scientific) following the manufacturers instructions for polyphenol rich tissues with a modification of the amount of processed material (where $1 \mathrm{~g}$ of fresh pulp was used) and the materia homogenization (where grinding of fresh pulp in sea sand directly in lysis solution was used). Extracted DNA was checked for the quality and quantity by Nanophotometer P-Class (Implen).

\section{PCR amplification, restriction analysis and amplicon separation}

Genomic data of Mal d 1 allergen stored in NCBI under the acession number AF020542.1 (Malus domestica major allergen Mal d 1 gene; complete sequence) were used for primer designation and data mining of the existed variable sequences of Mal d 1 allergen stored in public sequence databases by nucleotide BLAST algorithm (Altschul et al., 1990; Johnson et al., 2008). The strength of Mal d 1 promotor started at nt 3 and ended at nt 522 was chosen for PCR amplification.

Combi PPP master mix (TopBio) was used in PCR and the following time and temperature profile was used: $95^{\circ} \mathrm{C}, 3$ minutes, $35 \times\left(95^{\circ} \mathrm{C}\right.$ for 60 seconds; $58^{\circ} \mathrm{C}$ for 60 seconds; $72{ }^{\circ} \mathrm{C}$ for 60 seconds) and final $72{ }^{\circ} \mathrm{C}$ for 5 minutes. Restriction profiles of AF020542.1 acession was performed online using the Nebcutter V2.0 (nc2.neb.com/NEBcutter2) and Restriction mapper V3 (www.restrictionmapper.org). Restriction analysis temperature treatment of amplicons was performed by following the protocol of restriction enzymes provider (Ase I and Spe I; New England Biolabs). Restriction fragments were separated in 6\% PAGE gels stained by GelRed (Biotium).

\section{RESULTS AND DISCUSSION}

In spite of the very good knowledge about fruit allergen protein characteristics or their immunological interaction in sensitized patients (Rona et al., 2007), the knowledge about their expression characteristics in plants per se is very limited. The actually known information about the expression of Mal d 1 allergen and Ypr 10 promoter is as follows. Ypr10 genes were found to be induced by multiple stress factors. Application of abiotic stimuli, like salicylic acid and reduced glutathione significantly increased both, Ypr10*a-GUS activity in transgenic tobacco and transcriptional and translational expression of Mal d 1 in young apple leaves. Virus infection of the transformed tobacco plants strongly induced Ypr10*a-GUS transgene expression. After treatment with funga elicitors a clear increase in GUS activity and Mal d 1 expression was observed in young tobacco and apple leaves, respectively (Pühringer et al., 2000).

Apple allergens expression was reported by Botton et al. (2009) as to be significantly affected by shadowing, elevation, and storage, whereas water stress slightly influenced the expression of only two genes, in spite of the dramatic effect on both fruit size and vegetative growth of the trees.

Data minig was applied firstly to check the variability of different $\mathrm{Ypr} 10$ promotor (nt 3-522) possible stored in NCBI. Using the BLAST algorithm to Malus domestica taxid 3750, only two differences in nucleotide sequences were found (figure 1). In the case of T/A substitution, the Fai I restriction site (YAT/R) was identified.

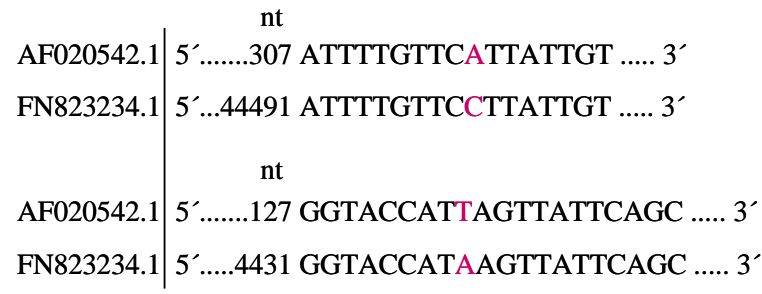

Figure 1 Comparison of variable sites of nt 3-522 of Ypr10 gene promotor in actual NCBI dataset.

Complete restriction map of the amplified part of YprlO gene promotor was analysed in the second step and two restriction endonucleases were chosen for the analysis of apple varieties used in the study - Ase I and Spe I. In silico cleavage by Ase I has resulted in four restriction fragment and cleavage by Spe I has resulted in two restriction fragments with the characteristics completed in figures $2-4$

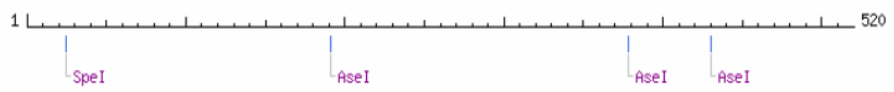

Figure 2 Schematic positions of restriction sites of Ase I and Spe I in the amplicon analysed in the study.

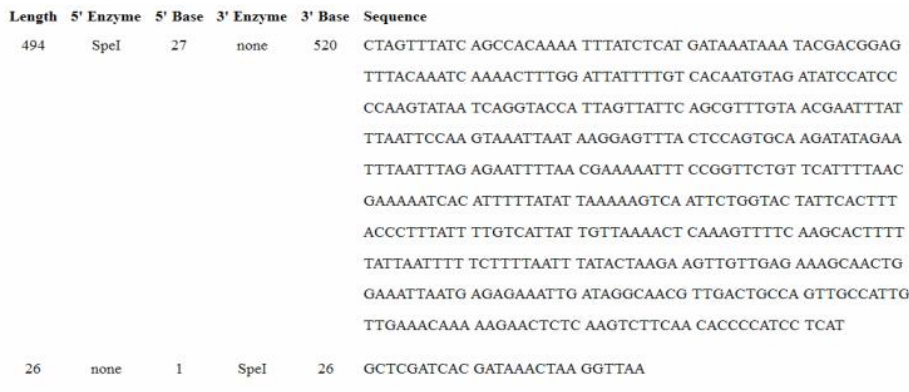

Figure 3 In silico restriction map of nt 3-522 of Ypr10 gene promotor stored in NCBI by Spe I.

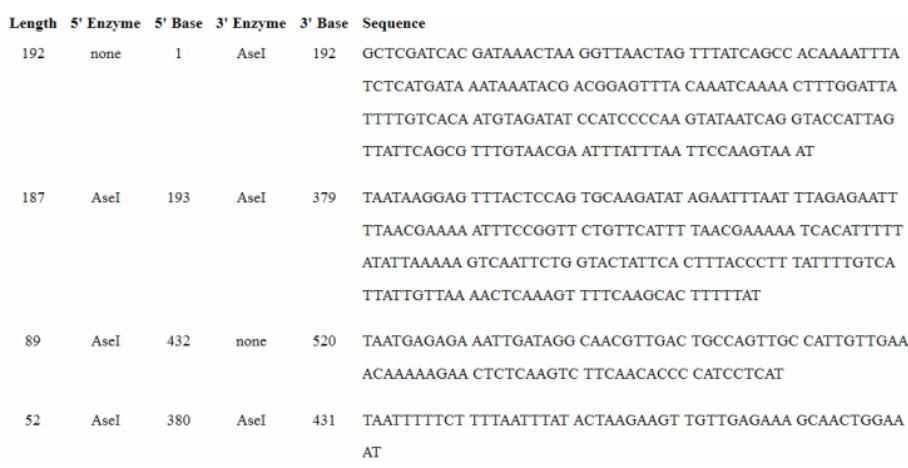

Figure 4 In silico restriction map of nt 3-522 of Ypr10 gene promotor stored in NCBI by Ase I.

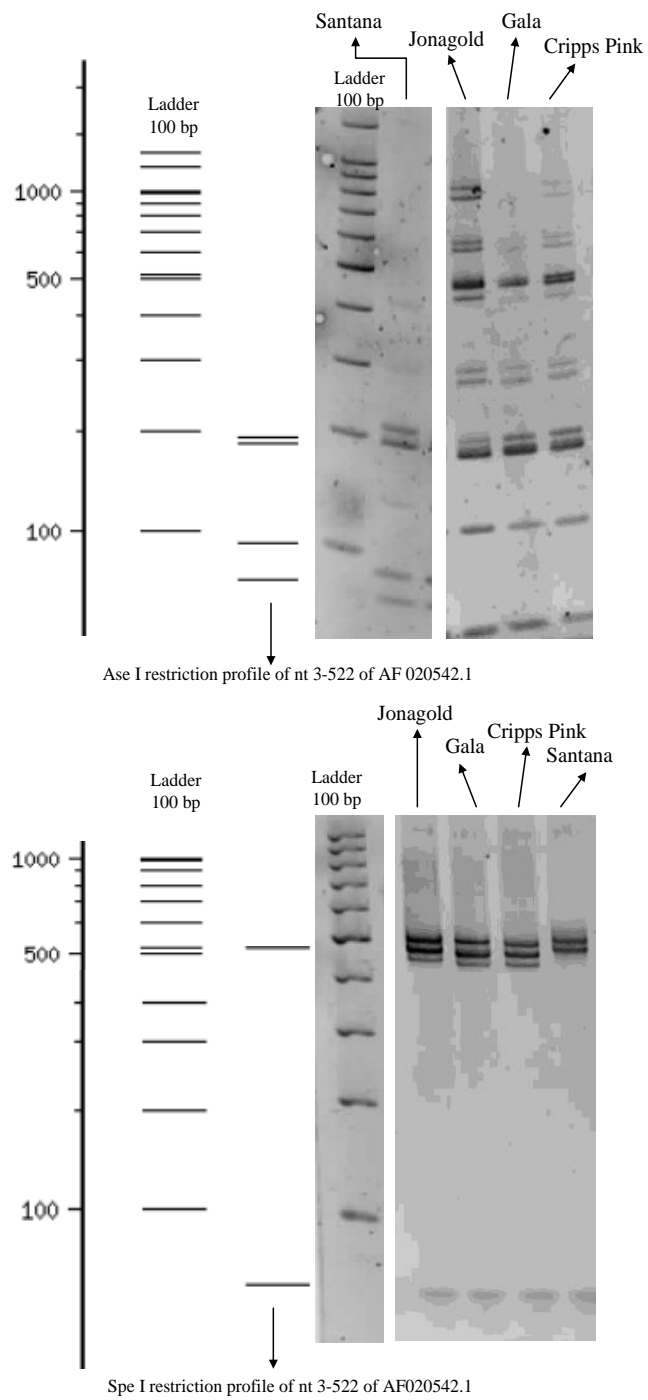

Figure 5 Restriction profiles of analysed amplicons compared to the predicted by virtual cleavage. 
Finally, PCR were performed using the extracted DNA of all of the analysed apple varieties and subsequent restriction cleavage was applied. Virtual cleavage maps were compared to the obtained restriction profiles (figure 5).

Virtual cleavage maps were based on the sequence of Malus domestica major allergen Mal d 1 gene that was used in the data mining analysis. This sequence was isolated from the apple variety McIntosh by (Pühringer et al., 2000) McIntosh is reported in the literature as one of the hypoallergenic varieties together with the Santana (Bolhaar et al., 2005; Kootstra et al., 2007) and Pink Lady (trade name of club cultivar Cripps Pink) (Vlieg-Boerstra et al., 2011, 2013).

Restriction profile of Santana variety was the same as the virtual profile of the McIntosh variety only in the case of the Ase I cleavage. All the others analysed varieties resulted in different cleavage profiles for Ase I. In total, 12 different restriction fragments were obtained for varieties Jonagold and Cripps Pink and 10 for variety Gala. Spe I restriction cleavage resulted also in three different cleavage pattern, but here, Gala and Cripps Pink profile were concordant and Santana was again different from all of the other analysed varieties. All of the analysed varieties resulted in four restriction fragments in the case of Spe I cleavage, but they differ in the lenght of the fragments. That is, why it can be supposed, that a wide natural variability exist for Mal d 1 allergen of apples among the varieties.

Mal d 1 aminoacids variability was reported by Bokszczanin et al. (2015) in the study, where new Mal d 1 alleles were identified among Polish Apple varieties. Seven variants of Mal d 1.01 were investigated with three new; three variants of Mal d 1.02 where two new were described; four variants of Mal d 1.04 with three new and one pseudoallele; seven different variants of Mal d $1.06 \mathrm{~A}$ where three new were described; six variants of Mal d 1.06B with four new and finally three variants of Mal d $1.06 \mathrm{C}$ where two new variants were described.

All these alleles result in 16 different protein izoforms in polish apple varieties.

\section{CONCLUSION}

Restriction analysis of the part of the Ypr10 gene promotor of Mal d 1 allergen of apples was performed in the study and a variability of obtained restriction patterns was described. Four varieties were used in the study - Santana, Cripps Pink, Jonagold and Gala. All the restriction fragments were compared to those that were prepared by virtual cleavage of the genomic sequence of McIntosh Apple variety stored in the NCBI. Different restriction profiles of the analysed part of the Mal d 1 allergen exist in apple varieties.

Acknowledgments: This research was supported by European Community under project no 26220220180: Building Research Centre "AgroBioTech" and by The Danube strategy project DS-2016-0051 Genomics, transcriptomics, digestomics and a mouse allergy of sensitization to allergenic lipid transfer proteins.

\section{REFERENCES}

Altschul, S.F., Gish, W., Miller, W., Myers, E.W., Lipman, D.J. (1990). Basic local alignment search tool. Journal of Molecular Biology, 215, 403-410.

Beuning, L., Bowen, J., Persson, H., Barraclough, D., Bulley, S., MacRae, E. (2004). Characterisation of Mal d 1-related genes in Malus. Plant Molecular Biology, 55, 369-388. DOI: https://doi.org/10.1007/s11103-004-0904-9

Bokszczanin, K.L., Przybyla, A.A., Krezdorn, N., Winter, P., Filipecki, M. (2015). Investigation of Mal d 1 Allelic Variants and Phylogenetic Diversity in Contemporary and Historical Polish Apple Cultivars. Journal of Agricultural Science, 7, 115-131. DOI: http://dx.doi.org/10.5539/jas.v7n11p115.

Bolhaar, S.T., Zuidmeer, L., Ma, Y., Ferreira, F., Bruijnzeel-Koomen, C.A., Hoffmann-Sommergruber, K., van Ree, R., Knulst, A.C. (2005). A mutant of the major apple allergen, Mal d 1, demonstrating hypo-allergenicity in the target organ by double-blind placebo-controlled food challenge. Clinical and Experimental Allergy, 35,1638-1644. DOI: http://10.1111/j.13652222.2005.02390.x

Botton A., Lezzer, P., Dorigoni, A., Ruperti, B., Ramina A. (2009). Environmental factors affecting the expression of apple allergen-encoding genes. The Journal of Horticultural Science and Biotechnology, ISA FRUIT Special issue: 182-187. DOI: http://dx.doi.org/10.1080/14620316.2009.11512618 Breiteneder H., Ebner, C. (2000). Molecular and biochemical clasification of plant-derived food allergen. Journal of Allergy and Clinical Immunology, 106, 27-36.

Gao, Z. S., Weg, W. E., Schaart, J. G., Arkel, G., Breiteneder, H., HoffmannSommergruber, K., Gilissen, L. J. (2005). Genomic characterization and linkage mapping of the apple allergen genes Mal d 2 (thaumatin-like protein) and Mal d 4 (profilin). Theoretical and Applied Genetics, 111(6), 1087-1097. DOI: http://dx.doi.org/10.1007/s00122-005-0034

Gilissen, L.J., Bolhaar, S.T., Matos, C.I., Rouwendal, G.J., Boone, M.J., Krens, F.A., Zuidmeer, L., Van Leeuwen, A., Akkerdaas, J., Hoffmann-Sommergruber, K., Knulst, A.C., Bosch, D., Van de Weg, W.E., Van Ree, R. (2005). Silencing the major Apple allergen Mal d 1 using the RNA interference approach. Journal of allergy and clinical immunology, 115, 364-369.
Johnson, M., Zaretskaya, I., Raytselis, Y., Merezhuk, Y., McGinnis, S., Madden, T. L. (2008). NCBI BLAST: a better web interface. Nucleic Acids Research, 36(Web Server issue), W5-W9 . DOI: http://doi.org/10.1093/nar/gkn201

Keresteš, J. et al. (2011). Zdravie a výživa l'udí. Bratislava: CAD PRESS, 2011 1040 s. ISBN 978-80-88969-57-0

Kiewning, D., Schmitz-Eiberger, M., (2014). Effects of long-term storage on Mal d 1 contents of four apple cultivars with initial low Mal d 1 contents. Journal of the Science of Food and Agriculture, 94,798 - 802. DOI: http://10.1002/jsfa.6448 Kollmann, D., Geroldinger-Simic, M., Kinaciyan, T., Huber, H., Ebner, Ch., Lidholm, J., Bohle, B. (2013). Recombinant Mal d 1 is a reliable diagnostic tool for birch pollen allergen - associated apple allergy. Journal of Allergy and Clinical Immunology, 132, $1008 . \quad$ DOI: http://dx.doi.org/10.1016/j.jaci.2013.05.030

Kootstra, H.S. Vlieg-Boerstra, B.J., Dubois, A.E. (2007). Assessment of the reduced properties of the Santana apple. Annals of Allergy, Asthma \& Immunology, 99, 522-525. DOI: http://10.1016/S1081-1206(10)60381-X

Luby, J. (2003). Taxonomic classification and brief history. Applies: botany, production and uses. CABI Publishing, CAB International, 2003. Ref. 42. s. 1-14 ISBN 085-1995-926

Pagliarani, G.,Paris, R., Arens, P., Tartarini, S., Ricci, G., Smulders, M.J.M., Weg, W.E. (2013). A qRT-PCR assay for the expression of Mal d 1 isoallergen genes. BMC Plant Biology, 13,51. DOI: http://dx.doi.org/10.1186/1471-2229-13-51

Petrů, V. et al. (1994). Alegie u dětí. Praha: Grada-Avicenum, 1994. 151 s. ISBN 80-7169-090-2.

Pühringer, H., Moll, D., Hoffmann-Sommergruber, K., Watillon, B., Katinger, H., Laimer da Câmara Machado, M. (2000). The promoter of an apple Ypr10 gene, encoding the major allergen Mal d 1, is stress- and pathogen-inducible. Plant Science, 152, 35-50. DOI: https://doi.org/10.1016/S0168-9452(99)00222$\underline{8}$.

Rona, R.J.,Keil, T., Summers, C., Gislason, D., Zuidmeer, L., Sodergren, E., Sigurdardottir, S.T., Lindner, T., Goldhahn, K., Dahlstrom, J., McBride, D., Madsen, C.(2007). The prevalence of food allergy: A meta-analysis. Journal of Allergy and Clinical Immunology , 120, 638-646. DOI http://doi.org/10.1016/j.jaci.2007.05.026

Somkuti, J., László, S. (2013). High pressure effects on allergen food protein. Biophysical chemistry, 183, 19-29.

Szamos,J., Takács, K., Szabó, E.E., Kovács, E., Gelencsér, É. (2011) Purification of natural Mal d 1 and Mal d 2 allergens and monitoring of their expression levels during ripening in Golden Delicious Apple. Food Research International, 44, 2674-2678. http://10.1016/j.foodres.2011.05.033

Vlieg-Boerstra, B.J., van de Weg, W.E., van der Heide, S., Kerkhof, M., Arens, P., Heijerman-Peppelman, G., Dubois, A.E. (2011). Identification of low allergenic apple cultivars using skin prick test and oral food challenges. Allergy, 66, 491- 498. DOI: http://10.1111/j.1398-9995.2010.02499.

Vlieg-Boerstra, B.J., van de Weg, W.E., van der Heide, S., Skypala, I., Bures, P., Ballmer-Weber, B.K., Hoffmann-Sommergruber, K., Zauli, D., Ricci, G., Dubois, A.E.(2013). Additional indications for the low allergenic properties of the apple cultivars Santana and Elise. Plant Foods and Human Nutrition, 68, 391- 395. DOI: http://10.1007/s11130-013-0385-6 